\title{
Prognostic value of noggin protein expression in patients with resected gastric cancer
}

Sang Hoon Chun ${ }^{1} \mathbb{D}$, Eun Young Kim² ${ }^{\mathbb{D}}$, Jung-Sook Yoon ${ }^{3}$, Hye Sung Won ${ }^{1} \mathbb{D}$, Kwangil Yim ${ }^{4}$, Hye Won Hwang ${ }^{5}$, Soon Auck Hong ${ }^{5}$ (D) Minho Lee ${ }^{6}$, Su Lim Lee ${ }^{7}$, Sung-Soo Kim ${ }^{8}$, Der Sheng Sun ${ }^{1+}$ (1) and Yoon Ho Ko ${ }^{1,9^{*}+}$ (D)

\begin{abstract}
Background: Noggin and RNA-binding protein for multiple splicing 2 (RBPMS2) are known to regulate the expression of smooth muscle cells, endothelial cells, and osteoblasts. However, the prognostic role of combined Noggin and RBPMS2 expression in resected gastric cancer (GC) is unclear.

Methods: A total of 163 patients with GC who underwent gastrectomy were included in this study. The expression of Noggin and RBPMS2 proteins in tumor cells at the tumor center and invasive front of resected GC was evaluated by immunohistochemistry, and in conjunction with clinicopathological parameters the patient survival was analyzed.

Results: RBPMS2 protein expression was high at the tumor center $(n=86,52.8 \%)$ and low at the invasive front $(n=$ $69,42.3 \%)$, while Noggin protein expression was high in both tumor center $(n=91,55.8 \%)$ and the invasive front $(n=90,55.2 \%)$. Noggin expression at the invasive front and tumor center was significantly decreased in advanced T stage, non-intestinal-type (invasive front, $P=0.008$ and $P<0.001$; tumor center lesion, $P=0.013$ and $P=0.001$ ). RBPMS2 expression at the invasive front was significantly decreased in non-intestinal-type and positive lymphatic invasion $(P<0.001$ and $P=0.013$ ). Multivariate analysis revealed that high Noggin protein expression of the invasive front was an independent prognostic factor for overall survival (hazard ratio [HR], 0.58; 95\% confidence interval $[\mathrm{Cl}] ; 0.35-0.97, P<0.036)$, but not at the tumor center ( $\mathrm{HR}, 1.35 ; 95 \% \mathrm{Cl} ; 0.81-2.26, P=0.251)$.

Conclusions: Our study indicates that high Noggin expression is a crucial prognostic factor for favorable outcomes in patients with resected GC.
\end{abstract}

Keywords: Gastric cancer, Noggin, RNA-binding protein for multiple splicing 2 (RBPMS2), Prognosis

\footnotetext{
* Correspondence: koyoonho@catholic.ac.kr

${ }^{\dagger}$ Der Sheng Sun and Yoon Ho Ko contributed equally to this work.

'Division of Oncology, Department of Internal Medicine, College of Medicine,

The Catholic University of Korea, Seoul, Republic of Korea

${ }^{9}$ Cancer Research Institute, College of Medicine, The Catholic University of Korea, Seoul, Republic of Korea

Full list of author information is available at the end of the article
}

(c) The Author(s). 2021 Open Access This article is licensed under a Creative Commons Attribution 4.0 International License, which permits use, sharing, adaptation, distribution and reproduction in any medium or format, as long as you give appropriate credit to the original author(s) and the source, provide a link to the Creative Commons licence, and indicate if changes were made. The images or other third party material in this article are included in the article's Creative Commons licence, unless indicated otherwise in a credit line to the material. If material is not included in the article's Creative Commons licence and your intended use is not permitted by statutory regulation or exceeds the permitted use, you will need to obtain permission directly from the copyright holder. To view a copy of this licence, visit http://creativecommons.org/licenses/by/4.0/. The Creative Commons Public Domain Dedication waiver (http://creativecommons.org/publicdomain/zero/1.0/) applies to the data made available in this article, unless otherwise stated in a credit line to the data. 


\section{Background}

Gastric cancer (GC) is the fourth most common cancer and the third leading cause of cancer-related death globally [1]. Recently, early diagnosis and the development of surgical techniques have led to a significant improvement in clinical outcomes of patients with resectable GC. The 5-year survival rate of patients with early GC is over 90\% [2]. Despite remarkable advances in targeted therapy for molecular targets, vascular endothelial growth factor receptor (VEGFR), and human epidermal growth factor receptor 2 (HER2) to improve patient survival in the setting of recurrent and metastatic GC, the prognosis of patients with recurrent and metastatic GC remains poor [3]. Thus, new molecular therapeutic targets and biomarkers are required to improve the survival of patients with GC.

Tumor stroma is composed of cancer-associated fibroblasts, immune cells, and other stromal cells around the cancer cells of extracellular matrix (ECM), which includes cell-adhesion molecules and ligands that play a role in tissue organization [4]. Besides, tumor-stroma interaction at the invasive front of the tumor represents a critical interface, where tumor progression and tumor cell dissemination occur due to the lack of cohesiveness, secretion of proteolytic enzymes, re-organization of the ECM, and increased cell proliferation [5].

Stromal gene expression or phenotype is one of the independent prognostic markers in various cancers including GC [6]. Recently, we identified a novel prognosisassociated four-gene signature comprising NOGGIN and RNA-binding protein for multiple splicing 2 (RBPMS2), cathepsin F (CTSF) and CUE domain containing 1 (CUEDC1), in resected GC using machine learning method [7] for effective stratification of 5-year survival outcomes. Noggin and RBPMS2 are known to regulate the expression of stromal cells, such as smooth muscle cells (SMCs), endothelial cells, and osteoblasts. Noggin protein is a glycosylated cysteine-knot protein that acts as an extracellular negative regulator of members in the transforming growth factor-beta superfamily that includes bone morphogenetic proteins (BMPs) [8]. Orthotopic expression of Noggin in endothelial cells results in the inhibition of cell migration and prevents the formation of endothelial cords in vitro, and Noggin inhibits angiogenesis even in the presence of pro-vasculogenic VEGF and fibroblastic growth factor-2 [9]. RBPMS2, a member of the RNA Recognition Motif family, is expressed in the vertebrate heart and gastrointestinal tract $[10,11]$. It is also an early marker of gastrointestinal smooth muscle precursor cells [12]. Perturbations in RBP expression and function play an important role in cancer initiation and progression. Of note, the two proteins interact with each other and regulate the early development and plasticity of digestive SMCs by inhibiting the BMP pathway [13].

However, the expression pattern and prognostic values of Noggin and RBPMS2 in GC has yet to be determined. Furthermore, the expression of stroma-related proteins were not known to have different clinical implications between the tumor center and invasive regions in GC. Therefore, we evaluated the expression of Noggin and RBPMS2 proteins in the tumor center and invasive front of resected GC and compared their relationship with clinicopathological parameters and clinical outcomes.

\section{Methods \\ Identification of molecular functions for NOGGIN and RBPMS2 with GSE database}

Genes predicting the prognosis of patients with $\mathrm{GC}$ were identified using the support vector machine algorithm for the microarray analysis of three publicly available gene expression profiles (GSE62254, GSE15459, and GSE15460) containing 822 samples of resected GC. To identify the molecular function enriched in NOGGIN and $R B P M S 2$ and positively correlated genes, we ranked genes based on their co-expression measured via linearby-linear association test with NOGGIN and RBPMS2. Subsequently, the ranked gene lists were used to identify the enriched KEGG pathways using Gene Set Enrichment Analysis (GSEA) via GSEA-P [14].

\section{Patients and tissue samples}

We performed a retrospective analysis of patients with GC at Uijeongbu St. Mary's Hospital of the Catholic Medical Center between 2001 and 2005. The inclusion criteria were: pathologically confirmed adenocarcinoma, radical resection without preoperative radiation or chemotherapy, removal of at least 15 or more lymph nodes, and available tissue specimens. Neoadjuvant chemotherapy or radiotherapy was permitted. Pathological staging was based on the 7th edition of the American Joint Committee on Cancer staging criteria.

\section{Tissue microarray construction and immunohistochemistry}

Tissue microarrays (TMA) were constructed for immunohistochemistry (IHC). The tissue cores $(2 \mathrm{~mm})$ were obtained from two representative paraffin blockembedded tumor regions in each case, containing invasive front, tumor cells or clusters at the perpendicularly deepest site of tumor invasion, and tumor center, the area that is equidistant for the tumor surface [15]. Briefly, the sections were deparaffinized and rehydrated using xylene and alcohol. Antigen retrieval was performed by heating the slides for $20 \mathrm{~min}$ in Tris-EDTA buffer ( $\mathrm{pH}$ 9.0) and then blocking the endogenous peroxidase activity by quenching with $3 \%$ hydrogen peroxide 
in methanol for $10 \mathrm{~min}$. The following steps in IHC were performed using R.T.U Vectastain Universal Quick kit (PK-7800; Vector Laboratories, Burlingame, CA) according to the manufacturer's instructions. The sections were incubated with primary antibodies against rabbit polyclonal Noggin (1:100, catalogue number ab16054; Abcam, Cambridge, UK) and rabbit polyclonal RBPMS2 (1:50, catalogue number ab170777; Abcam) overnight at $4{ }^{\circ} \mathrm{C}$. The antibody binding was visualized with ImmPACT DAB Peroxidase (HRP) Substrate kit (Vector, Burlingame, CA, USA). IHC staining of NOG and RBPMS2 was independently examined by two board certified pathologists (S.A.H. and K.Y.) who were blinded to clinicopathological variables. Discrepant cases between two observers were examined individually under a multiheaded microscope and discussed until an agreement was reached. The cytoplasmic expression of the tumor cells was considered positive. The staining intensity of the cytoplasmic expression at the invasive front and tumor center was evaluated, and graded semiquantitatively as follows: 0 , negative; 1 , weak; 2 , moderate; 3 , strong. We considered a staining intensity of 0 and 1 as low and 2 and 3 as high.

\section{Statistical analysis}

Independent Samples T-test was conducted to determine the association between protein expression and clinicopathological parameters. To study linear trends for the proportions of positive staining for the expression level of Noggin and RBPMS2 proteins, a crosstabulation was performed using chi-square tests. Overall survival (OS) was determined from the date of surgery to the date of death due to any cause or the last follow-up visit. Disease-free survival (DFS) was calculated from the date of surgery to the date of the first disease recurrence or last follow-up.

DFS and OS rates were measured using the KaplanMeier method, and statistical differences between the cumulative survival curves were evaluated using the log-rank test. Cox proportional hazards regression models were used to evaluate the significance of the prognostic factors. All variables with a $P$-value $<0.10$ in the univariate analysis were included in the multivariate analysis. Survival rates and hazard ratio (HR) s are reported with $95 \%$ confidence intervals (CIs). A $P$-value of $<0.05$ is considered statistically significant. The statistical analyses were performed using $\mathrm{R}$ statistical programming language version 3.4.1 (https:// www.r-project.org).

\section{Results}

Role of NOGGIN and RBPMS2 in stromal cell function

In the previous analysis of three publicly available gene expression profiles for GC, novel prognosis-associated four-gene signatures, such as NOGGIN, RBPMS2, CTSF, and CUEDC1, showed a moderate performance with an area under ROC curve (AUC) of 0.745 for the prediction of 5-year survival [7]. To identify the molecular pathways enriched in the co-expressed stroma-related genes, NOGGIN and RBPMS2, we conducted GSEA for KEGG pathways and identified the enriched pathways (Supplementary Fig. 1). Many pathways were common in both cases. "Focal adhesion" and "ECM receptor interaction" signatures were enriched and positively correlated with the expression of both NOGGIN and RBPMS2, respectively.

\section{Patients' characteristics}

A total of 163 paraffin blocks of tumor samples were prepared from patients who had undergone surgical gastrectomy. The clinical and pathological characteristics of the cohort are listed in Table 1 . The patient cohort consisted of 117 males (71.8\%) and 46 females (28.2\%), with a median age of 69 (35-92) years. According to the pathological TNM staging criteria, 26 patients (16.0\%) had stage I disease, $44(27.0 \%)$ patients had stage II disease, 75 (46.0\%) had stage III disease, and 18 (11.0\%) had IV disease. One hundred five patients (64.4\%) manifested regional lymph node metastases at the time of operation. The peritoneal seeding revealed 18 positive cases (11.0\%). Adjuvant chemotherapy was performed 72 patients (44.2\%) and there was no received adjuvant radiotherapy. During the median follow-up of 42.5 months (range, $0.1-121$ months) after surgical resection, $103(63.2 \%)$ died and $60(36.8 \%)$ were alive at the last follow-up. Disease recurrence was observed in 66 cases (40.5\%).

\section{Expression of noggin and RBPMS2 in normal gastric tissue compared with GC}

In normal gastric tissues, noggin and RBPMS2 were weakly expressed in gastric parietal cells, while foveolar cells generally test negative for both proteins (Supplementary Fig. 2). Considering the invasive front and tumor center, the high expression of Noggin was similar in the invasive front $(n=90,55.2 \%)$ and the tumor center $(n=91,55.8 \%)$. High expression of Noggin was observed in $72(61.3 \%)$ patients at both tumor center and invasive front (Fig. 1a-d). However, the high expression of RBPMS2 in tumor center $(n=86,52.8 \%)$ was more frequent than in the invasive front $(n=69,42.3 \%$, Table 2, Supplementary Table 1). Among 31 cases with the discrepant expression of RBPMS2 between the tumor center and invasive front, high RBPMS2 expression in the tumor center and low in the invasive front accounted for 24 (77.4\%) cases (Fig. 1e-h). 
Table 1 Baseline clinicopathological characteristics of patients with gastric cancer $(n=163)$

\begin{tabular}{|c|c|}
\hline Variables & Data \\
\hline Age, years, median (range) & $69.0(35-92$ \\
\hline$\leq 70$ & $93(57.1)$ \\
\hline$>70$ & $70(42.9)$ \\
\hline \multicolumn{2}{|l|}{ Sex } \\
\hline Male & $117(71.8)$ \\
\hline Female & $46(28.2)$ \\
\hline \multicolumn{2}{|l|}{ T stage } \\
\hline $\mathrm{T} 2$ & $38(23.3)$ \\
\hline $\mathrm{T} 3$ & $47(28.8)$ \\
\hline $\mathrm{T} 4$ & $78(47.9)$ \\
\hline \multicolumn{2}{|l|}{ N stage } \\
\hline NO & $58(35.6)$ \\
\hline N1 & $22(13.5)$ \\
\hline N2 & $22(13.5)$ \\
\hline N3 & $61(37.4)$ \\
\hline \multicolumn{2}{|l|}{ Pathological stage } \\
\hline । & $26(16.0)$ \\
\hline$\|$ & $44(27.0)$ \\
\hline III & $75(46.0)$ \\
\hline IV & $18(11.0)$ \\
\hline \multicolumn{2}{|l|}{ WHO differentiation } \\
\hline Well/moderate & $71(43.6)$ \\
\hline Poor & $90(55.2)$ \\
\hline \multicolumn{2}{|l|}{ Lauren's classification } \\
\hline Intestinal type & $78(47.9)$ \\
\hline Non-intestinal type ${ }^{a}$ & $85(52.1)$ \\
\hline \multicolumn{2}{|l|}{ Lymphatic invasion } \\
\hline No & $54(33.1)$ \\
\hline Yes & $109(66.9)$ \\
\hline \multicolumn{2}{|l|}{ Vascular invasion } \\
\hline No & $135(82.8)$ \\
\hline Yes & $28(17.2)$ \\
\hline \multicolumn{2}{|l|}{ RO resection } \\
\hline No & $18(11.0)$ \\
\hline Yes & $145(89.0)$ \\
\hline \multicolumn{2}{|l|}{ Adjuvant chemotherapy } \\
\hline No & $91(55.8)$ \\
\hline Yes & $72(44.2)$ \\
\hline \multicolumn{2}{|l|}{ EBV positivity } \\
\hline No & $153(93.9)$ \\
\hline Yes & $10(6.1)$ \\
\hline \multicolumn{2}{|l|}{ Peritoneal seeding } \\
\hline Negative & $145(89.0)$ \\
\hline Positive & $18(11.0)$ \\
\hline
\end{tabular}

Data are presented as number (\%) unless otherwise indicated

Included diffuse or mixed Lauren's type

EBV Epstein-Barr virus 

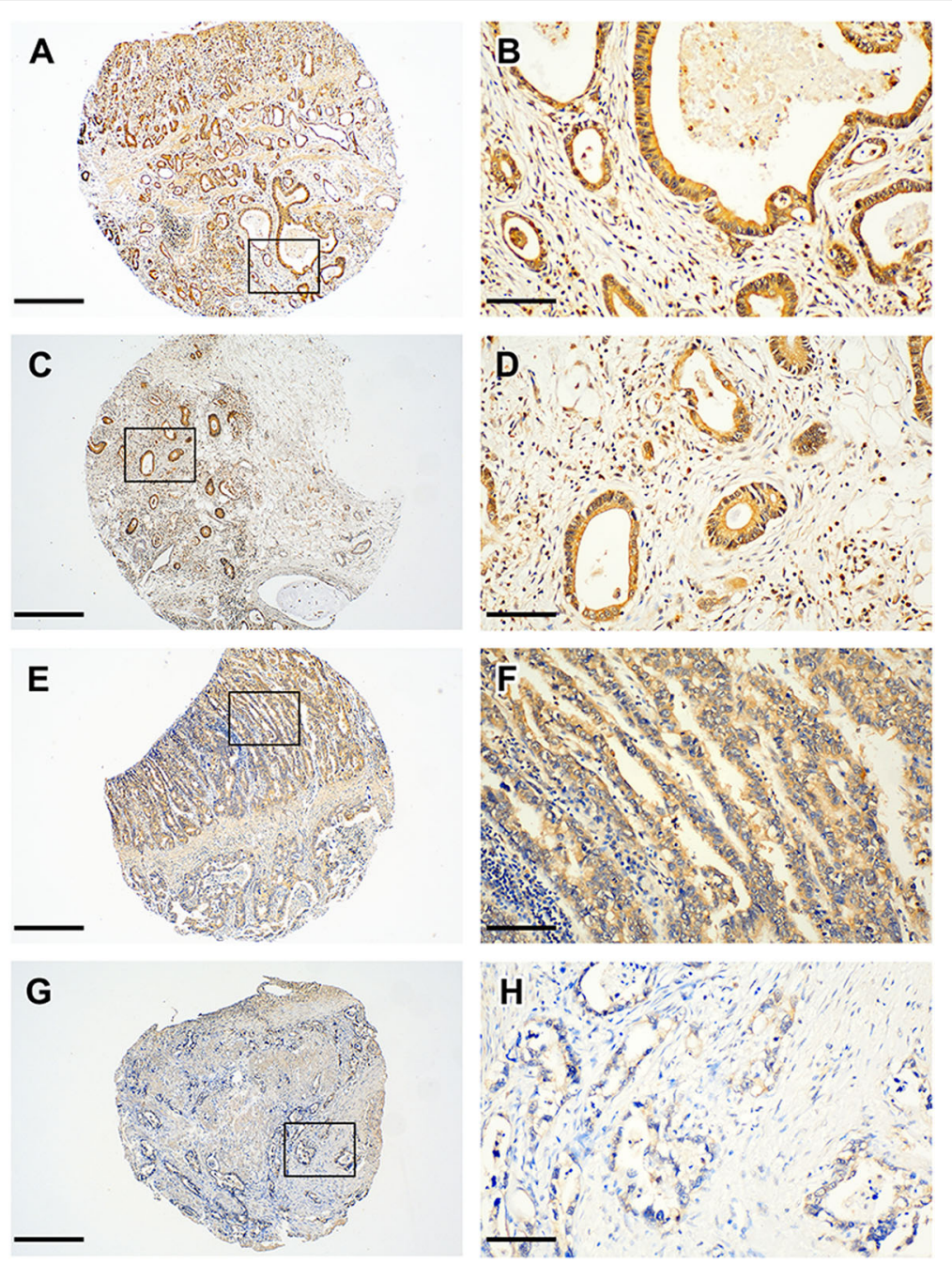

Fig. 1 Representative immunohistochemical staining for Noggin and RBMPS2 expression in the paired cases of invasive front and tumor center of gastric cancer. High Noggin expression in tumor center [(a Original magnification $\times 40$; scale bar, $500 \mu \mathrm{m})$ and (b Original magnification $\times 200$; scale bar; $100 \mu \mathrm{m})$ ] and deep invasive front [(c Original magnification $\times 40$; scale bar, $500 \mu \mathrm{m})$ ] and [(d Original magnification $\times 200$; scale bar, $100 \mu \mathrm{m})$ ] were detected; and high RBPMS2 expression in tumor center [(e Original magnification $\times 40$; scale bar; $500 \mu \mathrm{m})$ and (f Original magnification $\times 200$; scale bar; $100 \mu \mathrm{m})$ ]; and low RBPMS2 expression in deep invasive front [(g Original magnification $\times 40$; scale bar; $500 \mu \mathrm{m})$ and (h Original magnification × 200; scale bar; 100 mm)] were demonstrated. RBMPS2, RNA-binding protein for multiple splicing 2

\section{Clinicopathological characteristics of resected gastric cancer patients according to noggin and RBPMS2 protein expression}

The association between Noggin and RBPMS2 expression and clinicopathological features, including wellknown prognostic factors such as pathologic TNM stage, lymphatic and vascular invasion, Lauren's classification, Epstein-Barr virus (EBV) positivity and peritoneal seeding, was explored (Table 2 and Supplementary Table 1). Low Noggin expression at the invasive front and tumor center lesion was significantly correlated with advanced $\mathrm{T}$ stage and non-intestinal GC (invasive front, $P=0.008$ and $P<0.001$; tumor center lesion, $P=0.013$ and $P=$ 0.001 , respectively). Low RBPMS2 protein expression at the invasive front was associated with non-intestinal type and positive lymphatic invasion $(P<0.001$ and $P=$ 0.013 , respectively). Low expression of RBPMS2 protein in the tumor center was significantly correlated with the non-intestinal type and positive lymphatic invasion $(P<0.001$ and $P=0.047)$. Further, the investigated proteins showed significant associations between Noggin and RBPMS2 proteins in the invasive front as well as the tumor center $(P<0.001$, Table 3$)$.

\section{Prognostic value of noggin and RBPMS2 expression in resected GC}

We assessed the correlation between Noggin and RBPMS2 expression, and clinical prognosis using 
Table 2 Correlations between clinicopathological findings and Noggin or RBPMS2 protein expression in invasive front

\begin{tabular}{|c|c|c|c|c|c|c|}
\hline \multirow[t]{2}{*}{ Variables } & \multicolumn{3}{|c|}{ Noggin (invasive) } & \multicolumn{3}{|c|}{ RBPMS2 (invasive) } \\
\hline & Low $(n=73)$ & High $(n=90)$ & $P$-value & Low $(n=94)$ & High $(n=69)$ & $P$-value \\
\hline Pathological T stage & & & 0.008 & & & 0.132 \\
\hline $\mathrm{T} 2 / \mathrm{T} 3$ & $30(35.3)$ & $55(64.7)$ & & $45(52.9)$ & $40(47.1)$ & \\
\hline T4 & $43(55.1)$ & $35(44.9)$ & & $49(62.8)$ & $29(37.2)$ & \\
\hline Pathological N stage & & & 0.070 & & & 0.051 \\
\hline No & $21(36.2)$ & 37 (63.8) & & $28(48.3)$ & $30(51.7)$ & \\
\hline N1-N3 & $52(49.5)$ & $53(50.5)$ & & $66(62.9)$ & $39(37.1)$ & \\
\hline Lauren's classification & & & $<0.001$ & & & $<0.001$ \\
\hline Intestinal type & $24(30.8)$ & $54(69.2)$ & & $32(41.0)$ & $46(59.0)$ & \\
\hline Non-intestinal type $e^{a}$ & $49(57.6)$ & $36(42.4)$ & & $62(72.9)$ & $23(27.1)$ & \\
\hline Lymphatic invasion & & & 0.185 & & & 0.013 \\
\hline No & $21(38.9)$ & $33(61.1)$ & & $24(44.4)$ & $30(56.6)$ & \\
\hline Yes & $52(47.7)$ & $57(52.3)$ & & $70(64.2)$ & 39 (35.8) & \\
\hline Vascular invasion & & & 0.505 & & & 0.287 \\
\hline No & $60(44.4)$ & 75 (55.6) & & $76(56.3)$ & $59(43.7)$ & \\
\hline Yes & $13(46.4)$ & 15 (53.6) & & $18(64.3)$ & $10(35.7)$ & \\
\hline EBV positivity & & & 0.250 & & & 0.425 \\
\hline No & $67(43.8)$ & $86(56.2)$ & & 89 (58.2) & $64(41.8)$ & \\
\hline Yes & $6(60.0)$ & $(40.0)$ & & $5(50.0)$ & $5(50.0)$ & \\
\hline Peritoneal seeding & & & 0.234 & & & 0.141 \\
\hline Negative & $63(43.4)$ & $82(56.6)$ & & $81(55.9)$ & $64(44.1)$ & \\
\hline Positive & $10(55.6)$ & $8(44.4)$ & & $13(72.2)$ & $5(27.8)$ & \\
\hline
\end{tabular}

Data are presented as number (\%)

ancluded diffuse or mixed Lauren's type;

RBPMS2 RNA-binding protein for multiple splicing 2, EBV Epstein-Barr virus

Table 3 Relationship between the expression patterns of NOG and RBPMS2 proteins

\begin{tabular}{|c|c|c|c|c|c|c|c|c|c|c|}
\hline & & \multicolumn{3}{|c|}{ Noggin (invasive) } & \multicolumn{3}{|c|}{ RBPMS2 (invasive) } & \multicolumn{3}{|c|}{ Noggin (center) } \\
\hline & & Low & High & Total & Low & High & Total & Low & High & Total \\
\hline \multirow[t]{4}{*}{ RBPMS2 (invasive) } & Low & $62(84.9 \%)$ & $32(35.6 \%)$ & $94(57.7 \%)$ & & & & & & \\
\hline & High & $11(15.1 \%)$ & $58(64.4 \%)$ & 69 (42.3\%) & & & & & & \\
\hline & Total & 73,(100.0\%) & $90(100.0 \%)$ & 163,(100.0\%) & & & & & & \\
\hline & $p$-value & & $<0.001$ & & & & & & & \\
\hline \multirow[t]{4}{*}{ Noggin (center) } & Low & $54(74.0 \%)$ & $18(20.0 \%)$ & 72 (44.2\%) & $53(56.4 \%)$ & 19 (27.5\%) & $72(44.2 \%)$ & & & \\
\hline & High & 19 (26.0\%) & 72 (80.0\%) & 91 (55.8\%) & $41(43.6 \%)$ & $50(72.5 \%)$ & 91 (55.8\%) & & & \\
\hline & Total & 73(100.0\%) & $90(100.0 \%)$ & 163(100.0\%) & $94(100.0 \%)$ & $69(100.0 \%)$ & 163(100.0\%) & & & \\
\hline & $p$-value & & $<0.001$ & & & $<0.001$ & & & & \\
\hline \multirow[t]{4}{*}{ RBPMS2 (center) } & Low & 51 (69.9\%) & $26(28.9 \%)$ & 77 (47.2\%) & 70 (74.5\%) & $7(10.1 \%)$ & 78 (47.2\%) & $48(66.7 \%)$ & 29 (31.9\%) & 77 (47.2\%) \\
\hline & High & $22(30.1 \%)$ & $64(71.1 \%)$ & $86(52.8 \%)$ & $24(25.5 \%)$ & $62(89.9 \%)$ & $86(52.8 \%)$ & $24(33.3 \%)$ & $62(68.1 \%)$ & $86(52.8 \%)$ \\
\hline & Total & $73(100.0 \%)$ & $90(100.0 \%)$ & 163(100.0\%) & $94(100.0 \%)$ & $69(100.0 \%)$ & 163(100.0\%) & $72(100.0 \%)$ & $91(100.0 \%)$ & 163(100.0\%) \\
\hline & $p$-value & & $<0.001$ & & & $<0.001$ & & & $<0.001$ & \\
\hline
\end{tabular}


Kaplan-Meier curves with log-rank test. The elevated expression of Noggin at the invasive front was significantly associated with longer OS $(P=0.029$, Fig. $2 \mathrm{a})$, but not at the tumor center lesion $(P=0.476$, Fig. $2 b)$. No differences in OS were found between patients with high and low RBPMS2 expression in the invasive front $(P=0.925$, Fig. 2c) and tumor center $(P=0.446$, Fig. $2 d)$. Moreover, the expression of stromal proteins was strongly and significantly correlated with each other (Table 3 ). Thus, the 165 cases in the study were divided into 3 groups according to the number of proteins acquired, and a survival analysis was also performed (Fig. 3). Patients with high Noggin and RBPMS2 expression at the invasive front demonstrated a marginal significance for longer DFS compared with other groups $(P=0.111$, Fig. 3a), but not in OS ( $P=0.290$, Fig. 3c).

The factors affecting OS were further analyzed using Cox proportional hazards regression method. The univariate Cox proportional hazard ratios for OS were calculated.
Univariate analysis revealed that the following factors significantly worsened the OS: old age $(P<0.001)$, advanced pathologic $\mathrm{T}$ stage $(P<0.001)$, lymph node metastasis $(P<0.001)$, lymphatic invasion $(P<0.001)$, vascular invasion $(P=0.030)$, no R0 resection $(P<0.001)$, and peritoneal seeding positivity $(P<0.001)$. High Noggin protein expression and EBV positivity at the invasive front were significantly correlated with better $\operatorname{OS}(P=0.030$ and $P=0.020)$, but not the high Noggin protein expression in tumor center lesions and RBPMS2 protein expression at the invasive front and tumor center (Table 4). Results of multivariate Cox proportional hazards model showed that the high Noggin protein expression in invasive front $(\mathrm{HR}=0.58$; 95\% CI, 0.35-0.97; $P=0.036$ ) was a significant independent prognostic indicator for OS (Table 4). However, Noggin protein expression at the invasive front displayed a trend toward DFS in univariate analysis $(P=0.054)$, without reaching statistical significance in multivariate analysis (Supplementary Table 2 and Supplementary Fig. 3).

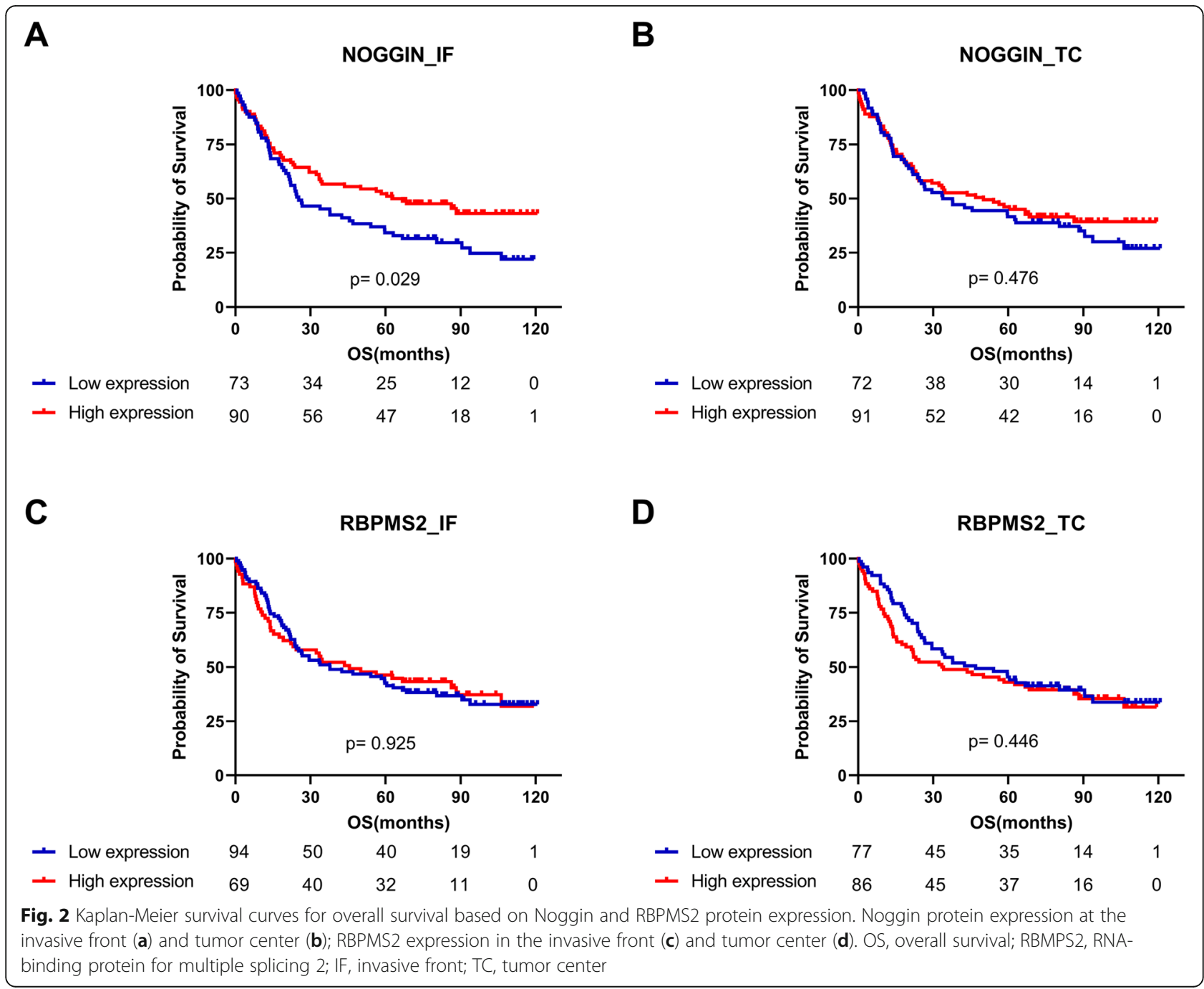




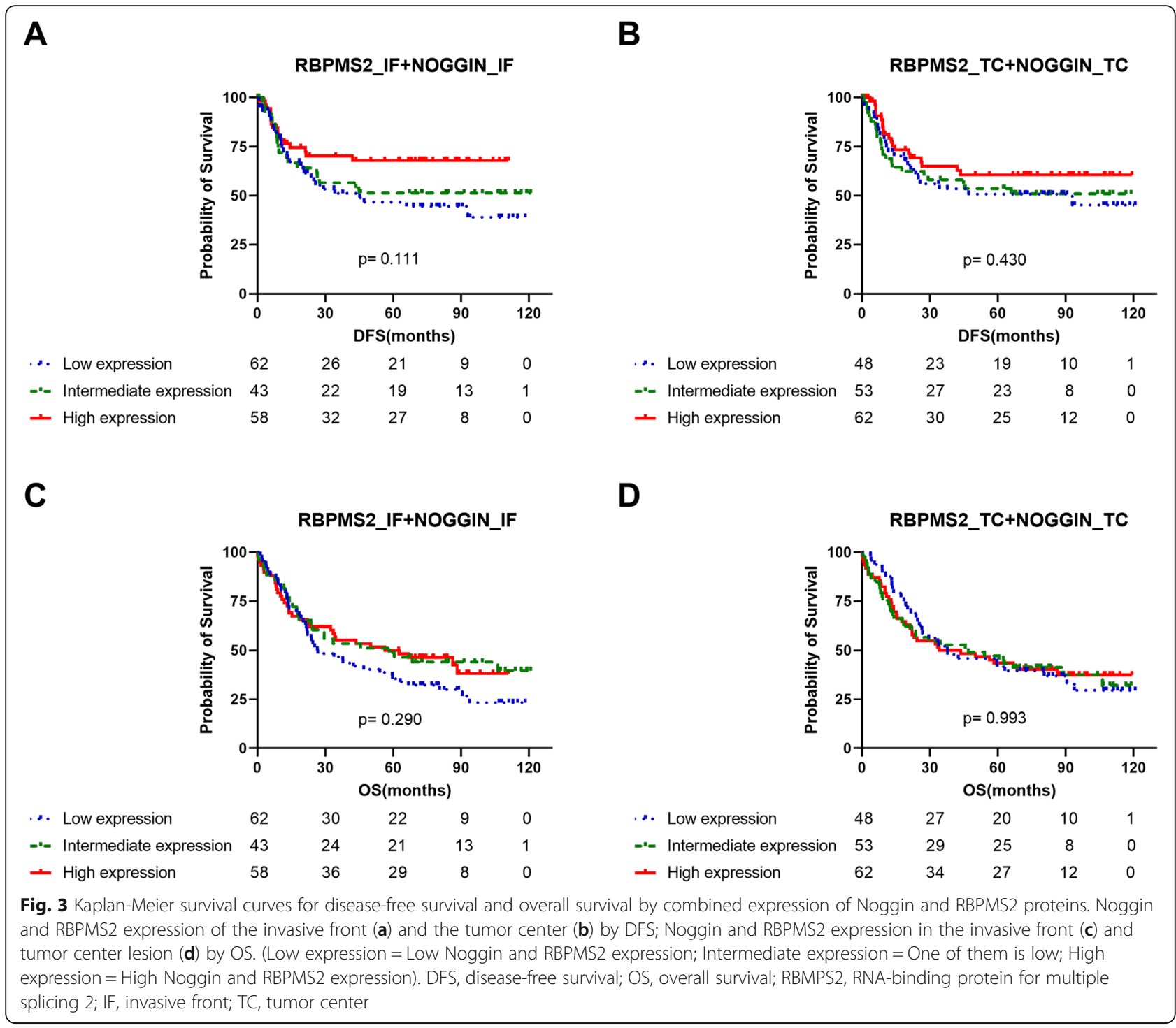

\section{Discussion}

The prognostic value of stroma-related proteins, Noggin and RBPMS2, expressed in the tumor center or invasive front, is complex and debatable. Previous reports also showed an ambiguous role of Noggin and RBPMS2 expression in GC $[16,17]$. In this study, we found that low Noggin protein expression at the invasive front of GC was more frequent in the group at an advanced $\mathrm{T}$ stage and in the non-intestinal Lauren's subtype, suggesting that the high Noggin expression was associated with a favorable clinical outcome in patients with resected GC. Its prognostic effect appears to be independent of established clinicopathological factors. To the best of our knowledge, this is the first report focusing on the clinical significance of Noggin at the invasive front of tumors in patients with resected GC.

The NOGGIN gene resides on chromosome 17q22, and is generally deleted in human cancers. It encodes a secreted polypeptide called Noggin. Noggin, a BMP antagonist, plays an essential role in bone formation and homeostasis, organogenesis, carcinogenesis, and bone metastasis $[8,18-20]$. The normal stomach tissues also exhibit moderate expression of Noggin, thus indicating its important role for BMP signaling pathway in the normal stomach [21]. Although the function of BMP signaling in tumorigenesis and tumor progression remains controversial, the overexpression of Noggin leads to decreased tumor size and reduced bone metastatic tumor growth in prostate cancer and lung cancer models [22, 23]. The tumor-suppressive function of NOGGIN is mediated by the inhibition of EMT-like transition [24], inhibition of Wnt signaling pathway [25] as well as the inhibition of BMP signaling $[8,20]$.

The growth of normal human gastric epithelial cells requires Noggin, EGF, R-spondin1, and Wnt3a [26]. Consistent with these findings, in this study, we 
Table 4 Univariate and multivariate analyses using Cox proportional-hazards model for all patients based on overall survival

\begin{tabular}{|c|c|c|c|c|c|c|}
\hline \multirow[t]{2}{*}{ Variables } & \multicolumn{3}{|c|}{ Univariate } & \multicolumn{3}{|c|}{ Multivariate } \\
\hline & $\mathrm{HR}$ & $95 \% \mathrm{Cl}$ & $P$-value & $\mathrm{HR}$ & $95 \% \mathrm{Cl}$ & $P$-value \\
\hline Age (> 70 vs. $\leq 70)$ & 2.203 & $1.497-3.270$ & $<0.001$ & 2.562 & $1.698-3.852$ & $<0.001$ \\
\hline Sex (female vs. male) & 1.172 & $0.771-1.793$ & 0.460 & & & 0.404 \\
\hline T stage (T4 vs. T2/3) & 2.772 & $1.850-4.144$ & $<0.001$ & 1.560 & $0.940-2.581$ & 0.085 \\
\hline N stage (N1-3 vs. N0) & 3.724 & $2.292-6.041$ & $<0.001$ & 3.007 & $1.663-5.461$ & $<0.001$ \\
\hline Lauren's classification (non-intestinal vs. intestinal) & 1.334 & $0.898-1.962$ & 0.154 & & & 0.675 \\
\hline Lymphatic invasion (yes vs. no) & 3.141 & $1.921-5.143$ & $<0.001$ & 1.481 & $0.790-2.789$ & 0.219 \\
\hline Vascular invasion (yes vs. no) & 1.713 & $1.054-2.761$ & 0.030 & 1.209 & $0.734-2.021$ & 0.455 \\
\hline RO resection (no vs. yes) & 2.662 & $1.552-4.580$ & $<0.001$ & 0.631 & $0.181-2.171$ & 0.461 \\
\hline High Noggin, invasive front (yes vs. no) & 0.653 & $0.444-0.958$ & 0.030 & 0.583 & $0.351-0.969$ & 0.036 \\
\hline High Noggin, center lesion (yes vs. no) & 0.867 & $0.591-1.283$ & 0.481 & & & \\
\hline High RBPMS2, invasive front (yes vs. no) & 0.983 & $0.655-1.449$ & 0.925 & & & \\
\hline High RBPMS2, center lesion (yes vs. no) & 1.162 & $0.792-1.710$ & 0.446 & & & \\
\hline EBV positivity (yes vs. no) & 0.188 & $0.046-0.768$ & 0.020 & 0.240 & $0.058-0.992$ & 0.049 \\
\hline Peritoneal seeding (positive vs. negative) & 3.102 & $1.549-4.584$ & $<0.001$ & 2.065 & $0.588-7.231$ & 0.256 \\
\hline
\end{tabular}

HR Hazard ratio, Cl Confidence interval, RBPMS2 RNA-binding protein for multiple splicing 2, EBV Epstein-Barr virus

observed that Noggin protein expression at the invasive front was more frequently upregulated in intestinal-type (68.4\%) than in mixed or diffuse GC (43.0\%) under Lauren's classification $(P<0.001)$, suggesting its role to maintain gastric gland morphology. On the other hand, our results suggest the negative prognostic effect of Noggin protein expression in the patients with resected GC. Consistent with these results, several previous studies showed that low levels of Noggin protein in combination with high BMP expression are associated with poor prognosis in esophageal carcinoma and increased metastasis in prostate and esophageal cancer [27, 28]. In contrast, Sun et al., in a study of 321 patients with GC and in vitro experiments, demonstrated that Noggin is associated with a poor prognosis of GC by promoting the proliferation of GC cells via the upregulation of epidermal growth factor receptor (EGFR). However, the different functions of Noggin protein were observed between intestinal- and diffuse type-GC cells, and the authors did not analyze its prognostic role according to Lauren's classification in the patients with GC [29]. In addition, the expression of BMPs, one of the targets of Noggin, is upregulated and correlated with poor survival of GC patients. In a study of 178 gastric tumor biopsies, the expression of BMP-2 and Matrix metallopeptidase (MMP)-9 showed a significant positive correlation with lymph node metastasis and a poor prognosis. The BMP2 signaling pathway enhances tumor metastasis in GC via sequential activation of the PI3K/AKT or MAPK pathway activation [30]. Further, we previously reported the prognostic role of Wnt antagonist, dickkopf1 (DKK1) in the same patient population, indicating that the high DKK1 expression, regardless of $ß$-catenin positivity, is an important prognostic factor for predicting tumor recurrence and survival in resected GC patients [31]. Interestingly, DKK1 and Noggin functionally cooperate in the organization of mammalian head [32], and mediate bone metastasis in patients with solid cancer [33]. These findings suggest that Noggin in conjunction with Wnt antagonist DKK1 may play a crucial role in bone metastasis in patients with diffuse-type GC and serve as the candidate biomarker for adjuvant therapy of bone metastasis [34].

RBPMS family is generally represented by two paralogs in vertebrates, RBPMS and RBPMS2 [35], which shuttle between nuclear and cytoplasmic fractions. RBPMS2 mediates the development and plasticity of gastrointestinal smooth muscle precursor cells [12] and is an early marker of gastrointestinal smooth muscle precursor cells [36], which positively regulates mRNA expression of Noggin. Ectopic expression of RBPMS2 in differentiated digestive smooth muscle precursor cells hinders their ability to contract and induces their proliferation leading to dedifferentiation, demonstrating that RBPMS2 expression is tightly regulated to avoid dedifferentiation of SMCs. In a previous report of GIST, RBPMS2 was upregulated in GISTs compared with normal adult gastrointestinal tissues, and its expression was higher in high-risk than in low-risk GIST specimens [37]. However, the increased expression of RBPMS2 has been correlated with favorable clinical outcomes in pancreatic cancer [38], which was similar to our data. Thus, a further study is still needed to elucidate the clinical role of RBPMS2 in GC. 
Interestingly, the expression of the Noggin protein at the invasive front is strongly correlated with prognostic factors, compared with those at the tumor center. Invasive cancer is a complex process that is related to cell attachment, matrix dissociation, migration, and tumor cell proliferation [39]. Thus, the invasive front of tumor cells is the most important area involved in prognosis and key molecular mechanisms in tumors aggravated via proliferation, angiogenesis, and loss of epithelial differentiation [5]. Previous studies also reported a discrepancy in protein expression between invasive front and tumor center based on prognostic or clinicopathological parameters [40-43]. In line with these findings, our data demonstrated that the expression of Noggin in the invasive front is a more representative parameter for prognostic evaluation of those proteins in advanced GC.

There are some limitations to our study. Because of the retrospective nature of this study, it might not reflect the biological properties of the entire population with GC. The investigated protein expression in the tumor center and the invasive front was compared via TMA instead of whole tumor sections. However, to compensate for the limitations of TMA, the tumor tissue was obtained in the most representative portion. Further, the differences in the interpretation of IHC staining method, tissue aging effects, staining techniques, and differences in enzyme antibodies used between studies contribute to the study limitations. Despite our limitations, we included a homogenous population that underwent standard surgical treatment for GC and was followed-up long-term.

\section{Conclusions}

In surgically resected GC, Noggin protein expression was strongly correlated with RBPMS2 expression. Besides, high Noggin expression in the invasive front of the tumor was independently and significantly associated with prognosis. Taken together, these results suggest that Noggin may act as a prognostic biomarker in patients with resected GC.

\section{Abbreviations \\ AUC: Area under ROC curve; BMPs: Bone morphogenetic proteins; \\ Cl: Confidence interval; CTSF: Cathepsin F; CUEDC1: CUE domain containing 1; DFS: Disease free survival; DKK1: Dickkopf1; EBV: Epstein-Barr virus; ECM: Extracellular matrix; EGFR: Epidermal growth factor receptor; GC: Gastric cancer; GSEA: Gene Set Enrichment Analysis; HER2: Human epidermal growth factor receptor 2; HR: Hazard ratio; IHC: Immunohistochemistry; MMP: Matrix metallopeptidase; OS: Overall survival; RBPMS2: RNA-binding protein for multiple splicing 2; SMCs: Smooth muscle cells; TMA: Tissue microarrays; VEGFR: Vascular endothelial growth factor receptor}

\section{Supplementary Information}

The online version contains supplementary material available at https://doi. org/10.1186/s12885-021-08273-x.

Additional file 1: Supplementary Figure 1. The molecular function of Noggin and RBPMS2. Gene set enrichment analysis (GSEA) of positively correlated genes with Noggin and RBPMS2 in GSE62254, GSE15459, and GSE15460 datasets showed "Focal adhesion" and "ECM receptor interaction" signatures, which were enriched and positively correlated with both Noggin and RBPMS2 expression, respectively (A). KEGG pathway analysis of positively correlated genes with Noggin and RBPMS2 associated with the GO terms shown on the left side (B). Normalized Enrichment Scores are represented by the bars, where the adjusted $p$ values (familywise error rate, FWER) $\leq 0.05$ are presented with a green bar or FWER $>0.05$ with a red bar. Supplementary Figure 2.

Immunohistochemical staining of noggin (A, original magnification $\times 1$ 200; scale bar, $100 \mu \mathrm{m})$ and RBPMS2 (B, original magnification $\times 200$; scale bar, $100 \mu \mathrm{m}$ ) in normal gastric mucosa. Foveolar cells are negative for noggin and RBPMS2, while both proteins are weakly expressed in parietal cells. Supplementary Figure 3. Kaplan-Meier survival curves for diseasefree survival were plotted according to Noggin and RBPMS2 protein expression. Noggin protein expression at the invasive front (A) and tumor center (B); RBPMS2 expression in the invasive front (C) and tumor center (D). DFS, disease-free survival; RBMPS2, RNA-binding protein for multiple splicing 2; IF, invasive front; TC, tumor center

Additional file 2: Supplementary Table 1 Clinicopathological factors and association according to RBPMS2 and NOG expression in tumor center lesions. Supplementary Table $\mathbf{2}$ Univariate and multivariate analyses of disease-free survival in all patients using Cox proportionalhazards model.

\section{Acknowledgements}

None.

\section{Authors' contributions}

SHC, EYK, DSS and YHK contributed to protocol development, data analysis, and drafted the manuscript. SHC, EYK, JSY, HSW, SAH, ML, DSS and YHK contributed to conceived of the study and participated its coordination. SHC, EYK, JSY, SAH, ML, DSS and YHK contributed to data check and information retrieval. SHC, HSW, SAH, ML, DSS and YHK researched the literature. SHC, EYK, KY, HWH, SLL, SSK, DSS and YHK designed the study and contributed to overall management of the study. All authors reviewed the manuscript and approved the final version of the manuscript.

\section{Funding}

The authors wish to acknowledge the financial support of The Catholic University of Korea, Uijeongbu St. Mary's Hospital Clinical Research Laboratory Foundation in the program years of 2017 (UJBCRL201701, Y. H. K) and 2018 (UJBCRL201743, Y. H. K). The funding bodies played no role in the design of the study and collection, analysis, and interpretation of data and in writing the manuscript.

\section{Availability of data and materials}

The datasets used and/or analysed during the current study are available from the corresponding author on reasonable request.

\section{Declarations}

\section{Ethics approval and consent to participate}

This study was approved by the Institutional Research Ethics Board of Uijeongbu St. Mary's Hospital and Bucheon St. Mary's Hospital of the Catholic University of Korea (No. UC20SESI0101 and HC19SESI0075) and was conducted in accordance with the tenets of the Declaration of Helsinki. Due to the retrospective nature of the study and the fact that no identifiable information is included, informed consent was not required according to laws of the Institutional Research Ethics Board of Uijeongbu St. Mary's Hospital and Bucheon St. Mary's Hospital of the Catholic University of Korea.

Consent for publication

Not applicable.

\section{Competing interests}

The authors declare that they have no competing interests. 


\section{Author details}

'Division of Oncology, Department of Internal Medicine, College of Medicine, The Catholic University of Korea, Seoul, Republic of Korea. ${ }^{2}$ Department of Surgery, College of Medicine, The Catholic University of Korea, Seoul, Republic of Korea. ${ }^{3}$ Uijeongbu St. Mary's Hospital Clinical Research Laboratory, The Catholic University of Korea, Seoul, Republic of Korea. ${ }^{4}$ Department of Hospital Pathology, College of Medicine, The Catholic University of Korea, Seoul, Republic of Korea. ${ }^{5}$ Department of Pathology, College of Medicine, Chung-Ang University, Seoul, Republic of Korea. ${ }^{6}$ Department of Life Science, Dongguk University-Seoul, Goyang, Republic of Korea. ${ }^{7}$ Department of Radiology, College of Medicine, The Catholic University of Korea, Seoul, Republic of Korea. ${ }^{8}$ Department of Internal Medicine, Division of Gastroenterology, College of Medicine, The Catholic University of Korea, Seoul, Republic of Korea. ${ }^{9}$ Cancer Research Institute, College of Medicine, The Catholic University of Korea, Seoul, Republic of Korea.

Received: 4 October 2020 Accepted: 29 April 2021

Published online: 17 May 2021

\section{References}

1. Bray F, Ferlay J, Soerjomataram I, Siegel RL, Torre LA, Jemal A. Global cancer statistics 2018: GLOBOCAN estimates of incidence and mortality worldwide for 36 cancers in 185 countries. CA Cancer J Clin. 2018;68(6):394-424. https://doi.org/10.3322/caac.21492.

2. Suzuki H, Oda I, Abe S, Sekiguchi M, Mori G, Nonaka S, et al. High rate of 5year survival among patients with early gastric cancer undergoing curative endoscopic submucosal dissection. Gastric Cancer. 2016;19(1):198-205. https://doi.org/10.1007/s10120-015-0469-0

3. Digklia A, Wagner AD. Advanced gastric cancer: current treatment landscape and future perspectives. World J Gastroenterol. 2016;22(8):240314. https://doi.org/10.3748/wjg.v22.i8.2403.

4. Baghban R, Roshangar L, Jahanban-Esfahlan R, Seidi K, Ebrahimi-Kalan A, Jaymand $\mathrm{M}$, et al. Tumor microenvironment complexity and therapeutic implications at a glance. Cell Commun Signal. 2020;18:1-19.

5. Rowe RG, Weiss SJ. Navigating ECM barriers at the invasive front: the cancer cell-stroma interface. Annu Rev Cell Dev Biol. 2009;25(1):567-95. https://doi. org/10.1146/annurev.cellbio.24.110707.175315.

6. Uhlik MT, Liu J, Falcon BL, Iyer S, Stewart J, Celikkaya H, et al. Stromal-based signatures for the classification of gastric cancer. Cancer Res. 2016;76(9): 2573-86. https://doi.org/10.1158/0008-5472.CAN-16-0022.

7. Lee M, Lee SL, Song KY, Kim SS, Ko YH. A 4-gene signature for prediction of gastric cancer prognosis based on SVM. Seoul: 44th Annual Meeting of Korean Cancer Association \& 4th International Cancer Conference; 2018. p. 3-5.

8. Walsh DW, Godson C, Brazil DP, Martin F. Extracellular BMP-antagonist regulation in development and disease: tied up in knots. Trends Cell Biol. 2010;20(5):244-56. https://doi.org/10.1016/j.tcb.2010.01.008.

9. Kang HW, Walvick R, Bogdanov A Jr. In vitro and in vivo imaging of antivasculogenesis induced by noggin protein expression in human venous endothelial cells. FASEB J. 2009;23(12):4126-34. https://doi.org/10.1096/fj. 08-127795.

10. Gerber W, Yatskievych TA, Antin PB, Correia KM, Conlon RA, Krieg PA. The RNA-binding protein gene, hermes, is expressed at high levels in the developing heart. Mech Dev. 1999;80(1):77-86. https://doi.org/10.1016/S092 5-4773(98)00195-6.

11. Wilmore HP, McClive PJ, Smith CA, Sinclair AH. Expression profile of the RNA-binding protein gene hermes during chicken embryonic development. Dev Dyn. 2005;233(3):1045-51. https://doi.org/10.1002/dvdy.20392.

12. Notarnicola C, Rouleau C, Le Guen L, Virsolvy A, Richard S, Faure S, et al. The RNA-binding protein RBPMS2 regulates development of gastrointestinal smooth muscle. Gastroenterology. 2012;143(3):687-97 e689.

13. Sagnol S, Yang Y, Bessin Y, Allemand F, Hapkova I, Notarnicola C, et al. Homodimerization of RBPMS2 through a new RRM-interaction motif is necessary to control smooth muscle plasticity. Nucleic Acids Res. 2014; 42(15):10173-84. https://doi.org/10.1093/nar/gku692.

14. Subramanian A, Kuehn H, Gould J, Tamayo P, Mesirov JP. GSEA-P: a desktop application for gene set enrichment analysis. Bioinformatics. 2007;23(23): 3251-3. https://doi.org/10.1093/bioinformatics/btm369.

15. Sentani K, Matsuda M, Oue N, Uraoka N, Naito Y, Sakamoto N, et al. Clinicopathological significance of MMP-7, laminin $\gamma 2$ and EGFR expression at the invasive front of gastric carcinoma. Gastric Cancer. 2014;17(3):412-22. https://doi.org/10.1007/s10120-013-0302-6.

16. Peng $Y$, Wu Q, Wang L, Wang H, Yin F. A DNA methylation signature to improve survival prediction of gastric cancer. Clin Epigenetics. 2020;12(1):15. https://doi.org/10.1186/s13148-020-0807-X.

17. Zhang J, Ge Y, Sun L, Cao J, Wu Q, Guo L, et al. Effect of bone morphogenetic protein-2 on proliferation and apoptosis of gastric cancer cells. Int J Med Sci. 2012;9(2):184-92. https://doi.org/10.7150/ijms.3859.

18. Kang HW, Gupta S, Bogdanov A Jr. Orthotopic expression of noggin protein in cancer cells inhibits human lung carcinoma growth in vivo. Mol Imaging Biol. 2012;14(4):480-8. https://doi.org/10.1007/s11307-011-0518-y.

19. Schwaninger $R$, Rentsch CA, Wetterwald A, van der Horst $G$, van Bezooijen $R L$, van der Pluijm $G$, et al. Lack of noggin expression by cancer cells is a determinant of the osteoblast response in bone metastases. Am J Pathol. 2007;170(1):160-75. https://doi.org/10.2353/ajpath.2007.051276.

20. Patel SR, Gordon J, Mahbub F, Blackburn CC, Manley NR. Bmp4 and noggin expression during early thymus and parathyroid organogenesis. Gene Expr Patterns. 2006;6(8):794-9. https://doi.org/10.1016/j.modgep.2006.01.011.

21. Laurila R, Parkkila S, Isola J, Kallioniemi A, Alarmo EL. The expression patterns of gremlin 1 and noggin in normal adult and tumor tissues. Int J Clin Exp Pathol. 2013;6(7):1400-8.

22. Feeley BT, Liu NQ, Conduah AH, Krenek L, Roth K, Dougall WC, et al. Mixed metastatic lung cancer lesions in bone are inhibited by noggin overexpression and rank:fc administration. J Bone Miner Res. 2006;21(10): 1571-80. https://doi.org/10.1359/jbmr.060706.

23. Virk MS, Petrigliano FA, Liu NQ, Chatziioannou AF, Stout D, Kang CO, et al. Influence of simultaneous targeting of the bone morphogenetic protein pathway and RANK/RANKL axis in osteolytic prostate cancer lesion in bone. Bone. 2009;44(1):160-7. https://doi.org/10.1016/j.bone.2008.09.009.

24. Busch C, Drews U, Eisele SR, Garbe C, Oppitz M. Noggin blocks invasive growth of murine B16-F1 melanoma cells in the optic cup of the chick embryo. Int J Cancer. 2008;122(3):526-33. https://doi.org/10.1002/ijc.23139.

25. Bayramov AV, Eroshkin FM, Martynova NY, Ermakova GV, Solovieva EA, Zaraisky AG. Novel functions of noggin proteins: inhibition of Activin/nodal and Wnt signaling. Development. 2011;138(24):5345-56. https://doi.org/1 0.1242/dev.068908.

26. Bartfeld S, Bayram T, van de Wetering M, Huch M, Begthel H, Kujala P, et al. In vitro expansion of human gastric epithelial stem cells and their responses to bacterial infection. Gastroenterology. 2015;148(1):126-36 e126.

27. Yuen HF, McCrudden CM, Grills C, Zhang SD, Huang YH, Chan KK, et al. Combinatorial use of bone morphogenetic protein 6, noggin and SOST significantly predicts cancer progression. Cancer Sci. 2012;103(6):1145-54. https://doi.org/10.1111/j.1349-7006.2012.02252.x.

28. Yuen HF, Chan YP, Cheung WL, Wong YC, Wang X, Chan KW. The prognostic significance of BMP-6 signaling in prostate cancer. Mod Pathol. 2008;21(12):1436-43. https://doi.org/10.1038/modpathol.2008.94.

29. Sun Z, Gao X, Zabkiewicz C, Ruge F, Xie M, Cai S, et al. Noggin is associated with a poor prognosis of gastric cancer by promoting the proliferation of gastric cancer cells via the upregulation of EGFR. Int J Oncol. 2020;57(3): 813-24. https://doi.org/10.3892/ijo.2020.5081.

30. Kang MH, Oh SC, Lee HJ, Kang HN, Kim JL, Kim JS, et al. Metastatic function of BMP-2 in gastric cancer cells: the role of PI3K/AKT, MAPK, the NF-kappaB pathway, and MMP-9 expression. Exp Cell Res. 2011;317(12):1746-62. https:// doi.org/10.1016/j.yexcr.2011.04.006.

31. Hong SA, Yoo SH, Lee HH, Sun S, Won HS, Kim O, et al. Prognostic value of Dickkopf-1 and ss-catenin expression in advanced gastric cancer. BMC Cancer. 2018;18(1):506. https://doi.org/10.1186/s12885-018-4420-8.

32. del Barco Bl, Davidson G, Grone HJ, Westphal H, Niehrs C. Dkk1 and noggin cooperate in mammalian head induction. Genes Dev. 2003;17(18):2239-44.

33. Dai J, Hall CL, Escara-Wilke J, Mizokami A, Keller JM, Keller ET. Prostate cancer induces bone metastasis through Wnt-induced bone morphogenetic protein-dependent and independent mechanisms. Cancer Res. 2008;68(14):5785-94. https://doi.org/10.1158/0008-5472.CAN-07-6541.

34. Göbel A, Kuhlmann JD, Link T, Wimberger $P$, Browne AJ, Rauner $M$, et al. Adjuvant tamoxifen but not aromatase inhibitor therapy decreases serum levels of the Wnt inhibitor dickkopf-1 while not affecting sclerostin in breast cancer patients. Breast Cancer Res Treat. 2017;164(3):737-43. https://doi. org/10.1007/s10549-017-4296-3.

35. Hoffman DW, Query CC, Golden BL, White SW, Keene JD. RNA-binding domain of the a protein component of the U1 small nuclear ribonucleoprotein analyzed by NMR spectroscopy is structurally similar to 
ribosomal proteins. Proc Natl Acad Sci U S A. 1991;88(6):2495-9. https://doi. org/10.1073/pnas.88.6.2495

36. Le Guen L, Notarnicola C, de Santa BP. Intermuscular tendons are essential for the development of vertebrate stomach. Development. 2009;136(5):791801. https://doi.org/10.1242/dev.029942.

37. Hapkova I, Skarda J, Rouleau C, Thys A, Notarnicola C, Janikova M, et al. High expression of the RNA-binding protein RBPMS2 in gastrointestinal stromal tumors. Exp Mol Pathol. 2013;94(2):314-21. https://doi.org/10.1016/j. yexmp.2012.12.004.

38. García-García A-B, Gómez-Mateo MC, Hilario R, Rentero-Garrido P, MartínezDomenech A, Gonzalez-Albert V, et al. mRNA expression profiles obtained from microdissected pancreatic cancer cells can predict patient survival. Oncotarget. 2017;8(62):104796-805. https://doi.org/10.18632/oncotarget.2 0076.

39. Ahn B, Chae YS, Kim CH, Lee Y, Lee JH, Kim JY. Tumor microenvironmental factors have prognostic significances in advanced gastric cancer. APMIS. 2018:126(10):814-21. https://doi.org/10.1111/apm.12889.

40. Horree N, van Diest PJ, Sie-Go DM, Heintz AP. The invasive front in endometrial carcinoma: higher proliferation and associated derailment of cell cycle regulators. Hum Pathol. 2007;38(8):1232-8. https://doi.org/10.1016/ j.humpath.2007.01.008.

41. Karamitopoulou E, Zlobec I, Panayiotides I, Patsouris ES, Peros G, Rallis G, et al. Systematic analysis of proteins from different signaling pathways in the tumor center and the invasive front of colorectal cancer. Hum Pathol. 2011;42(12):1888-96. https://doi.org/10.1016/j.humpath.2010.06.020.

42. Zlobec I, Lugli A. Invasive front of colorectal cancer: dynamic interface of pro-/anti-tumor factors. World J Gastroenterol. 2009;15(47):5898-906. https://doi.org/10.3748/wjg.15.5898.

43. Luo WR, Yao KT. Cancer stem cell characteristics, ALDH1 expression in the invasive front of nasopharyngeal carcinoma. Virchows Arch. 2014;464(1):3543. https://doi.org/10.1007/s00428-013-1508-z.

\section{Publisher's Note}

Springer Nature remains neutral with regard to jurisdictional claims in published maps and institutional affiliations.

Ready to submit your research? Choose BMC and benefit from:

- fast, convenient online submission

- thorough peer review by experienced researchers in your field

- rapid publication on acceptance

- support for research data, including large and complex data types

- gold Open Access which fosters wider collaboration and increased citations

- maximum visibility for your research: over $100 \mathrm{M}$ website views per year

At $\mathrm{BMC}$, research is always in progress.

Learn more biomedcentral.com/submissions 